\title{
The Hypocrisy of Corruption Eradication in Nigeria
}

\author{
Ezonbi, Boumo \\ Department Of History And International Studies Nigeria Police Academy,Wudil-Kano State,Nigeria
}

\begin{abstract}
The paper will open with a rhetorical question that we need to answer or refuse to answer. "Are we serious with corruption eradication in Nigeria?" what I mean is that we are all hypocritical about our concern over corruption. The paper observes that the ruling elites lack the kind of philosophical and ideological vision and orientation that is committed to developing "a dream society" they have no dream beyond the satisfaction of their desire, often those who are ostensibly in pursuit of transparency or those fighting corruption are invariably caught in the very act of corruption. Most time people are incensed that someone else is doing the stealing and not them. The paper concludes that corruption is a symptom of numerous difficulties within contemporary societies, the nearer he gets to the opportunity, the less his noise. It involves more than one party, our mind sets are corrupt, and once our eyes are open for us to differentiate black from white. Corruption can be systematic in nature and affect the whole life of an organization or society.
\end{abstract}

Key Words: Corruption, Economy, Eradication, Hypocrisy

\section{Introduction}

The high level of corruption has reached such an alarming stage in Nigeria that something must be done. Regrettably nothing has been done. The cost of governance in Nigeria is comparatively one of the highest and most expensive in the world. The dubious duplication of functions, financial recklessness, nepotism and cronyism in recruitment are largely influenced by the establishment of unnecessary government parastatals and agencies which also promote corrupt practices. This forms the headline of most Nigerian daily newspapers, in the pre and post independence era. There are many unresolved problems in Nigeria, but the issue of the upsurge in corruption is troubling, and the damage it has done to the polity is astronomical. The menace of corruption leads to slow movements of files in offices, police extortion, tollgates and slow traffic on the high ways, port congestion, queues at passport offices and petrol and gas stations, ghost workers syndrome, election irregularities among others. The effort to introduce anti corruption institutions in the past and recent times, especially the Economic and Financial Crimes Commission (EFCC), the Independent Corrupt Practices and Other Related Offences Commission (ICPC) and the National Extractive Industries Transparency Initiative (NEITI) proves abortive. In spite of these efforts, the level of corruption is still of serious concern and remains the greatest challenge to the Nigerian polity. Therefore, this paper holds the general thesis that, we are all hypocritical in the fight against corruption in Nigeria. The paper is organized into five parts. The first part is the introduction which gives a grasp of the paper, two tries to look at the subject matter as seen by different writers. The third part brings to light, the categorized corruption as experienced in Nigeria while the fourth part captures the central thesis of the paper and the last part try to make an input on how corruption can be reduced. The method adopted for this research was basically secondary data. In the next section we will try to clarify the subject matter of the paper.

\section{Conceptual Clarification}

For us to meaningful understand the central theme in respect to the Nigerian situation, there is the need to have a grasp of the concept as viewed by different writers and scholars. According to Mua'azu, M.M, the word corruption has varied meanings depending on the political culture and civilization of the people. In many Nigerian communities a man or community of men can give or send a gift to an officer, in appreciation of his good performance. This is called 'gaisuwa' in Hausa while in the western culture, that is corruption. Likewise if you bend a rule or a procedure to favour somebody, although in western civilization may be defended as a discretionary power of the officer, which may be covered by the constitution, but in another legal procedure, that will be called a corrupt practice. He emphasized that, in many cultures, including Nigeria's corruption is reduced to taking money to give something of a public nature. It is far beyond that. ${ }^{1}$

Ruzindana asserts that, corruption in Africa is a problem of routine deviation from established standards and norms by public officials and parties with whom they interact. He also identified the types of corruption in Africa as bribery, private gain, and other benefits to non-existent workers and pensioners (called ghost workers). The dishonest and illegal behaviour exhibited especially by people in authority for their personal gain. ${ }^{2}$ In this context as a result of the fluidity and the evolving nature of the concept, the United 
Nation (UN) has adopted a descriptive approach and criminalization of the act to describe what act is corrupt. The UN clearly highlighted bribery, embezzlement illicit enrichment, abuse of office, laundering of proceeds of corruption, obstruction of justice, ethic, as corrupt acts. ${ }^{3}$

The Independent Corrupt Practices Commission (ICPC) Act, 2000, views corrupt acts to include "bribery, fraud and other related offences". The vision 2010 committee defines corruption as "all those improper actions or transactions aimed at changing the normal course of events, judgments and position of trust". ${ }^{4}$ In another vein, Ndubisi asserts that corruption is any act by a public official which violates the accepted standard of behaviour in order to serve private or public ends. The end which this behaviour will serve may be social, economic or political. These standards may be legal or conventional. The emphasis is on the violation of such legal or conventional norms for private gain. Private gain will include gains in cash or kind for oneself, one's relative or friends. ${ }^{5}$ The World Bank defines corruption as;

The abuse of public office for private gains. Public office is abused for private gain when an official accepts, solicits, or extorts a bribe. It is also abused when private agents actively offer bribes to circumvent public policies and processes for competitive advantages or profit. Public office can also be abused for personal benefit even if no bribery occurs, through patronage and nepotism, the theft of state assets, or the diversion of state resources. ${ }^{6}$

Within this context, it is not an easy task to define corruption. The uneasiness in defining corruption is because it has many manifestations, dimensions and forms. Most especially defining corruption in Nigeria is difficult because of the gamut of what comes under the appellation "corrupt practices." In the words of Daniel J $\mathrm{S}$ views corruption in Nigeria,

When Nigerians talk about corruption, they refer not only to the abuse of state offices for some kind of private gain but also to a whole range of social behaviour in which various forms of morally questionable deception enable the achievement of wealth, power or prestige as well as much more mundane ambitions. Nigeria notion of corruption encompasses everything from government bribery and graft, rigged, elections; and fraudulent business deals, to the diabolical abuse of occult powers, medical quackery, cheating in school, and even deceiving a lover. ${ }^{7}$

In addition, corruption is a behaviour which deviates from the formal duties of a public role, because of private (gains), regarding (personal, close family, private clique, pecuniary or status gains. It is a behaviour which violates rules against the exercise of certain types of (duties) for private (gains) regarding influence. ${ }^{8}$ In the light of this, Banifield Edward puts it that, this definition includes such behaviour as bribery (use of a reward to prevent the judgment of a person in a position of trust); nepotism (bestowal of patronage by reason of ascriptive relationship rather than merit); and misappropriation (illegal appropriation of public resources for private uses. ${ }^{9}$ To cap it all, Osoba captures corruption as an "anti-social behaviour conferring improper benefits contrary to legal and moral norms, and which undermine the authorities" to improve the living conditions of the people. ${ }^{10}$

Gray, C.W and Kaufmann, D view corruption as those acts including "bribery and extortions involving at least two parties and other wrongdoings that a public official can carry out alone including fraud and embezzlement". ${ }^{11}$ This is manifested in government circle in the form of appropriation of public assets for private use and embezzlement of public funds. He further stresses that; this manifestation is linked to appointments and award of contracts by political office holders not on the basis of competence but on personal relationship, political affiliation and patronage. ${ }^{12}$ Having defined corruption as seen by different scholars in relation to general and specific to Nigerian situation, the next section will look at the nature and characteristic of corruption.

\section{THE NATURE AND CHARACTERISTICS OF CORRUPTION IN NIGERIA.}

For the purpose of this paper we will look at some form of corruption that is prevalent in Nigeria. Some studies have taken a more holistic approach in the discussion of corruption by categorizing it into many forms and sub-divisions. These are political corruption (grand), Bureaucratic corruption (petty) and electoral corruption.

Political corruption manifest in elections such as the manipulation to obtain or remain in power. Political positions are scarce and the prizes of office are high, hence, the competition of such resourcespositions-involves every possible extra -legal means through corruption in order to over come obstacles of opposition. Political corruption is sometimes seen as similar to "corruption of greed" as it affects the manner in 
which decisions are made, as it manipulates political institutions, rules and procedure, and distorts the institutions of government. ${ }^{13}$

Economic corruption, this is in the sphere of business world. Dogonyaro posited two types of corruption in the business world, each corresponds to the group or organization involved. The first is in trading and distribution of goods. This involves and perpetuates corruption by protecting, hoarding and also speculation on commodities. The second involves general contractors who operate through large financial conspiracy with power holders, dictating policies for states and federal government. ${ }^{14}$ That is corruption in business relationship, which is now very common even in international business.

Bureaucratic corruption, which operates at the level of bureaucracy and often involves perversion of due process. Bureaucratic corruption involves buying favour from bureaucrats who formulate and administer government economic and political policies. The areas chiefly involved are the acquisition of foreign exchange, import licenses, industrial establishment, avoidance of tax and the like. Gould, J.J observes in this connection that "it is true that there are many situations in which people press bribes on officials, tempting them away from the part of probity". ${ }^{15} \mathrm{He}$ further argues that in some cases officials are expected to be bribe in almost everything, and that "worse still, they use their enormous power of delay to force people to bribe them" such bribes and corrupt payments according to Left, $\mathrm{H} \mathrm{N}$ are not legitimized by proper government process, rather they are appropriated by the bureaucrats, not by the state, and they involve subversion of government's political and economic politics. ${ }^{16}$ It is generally believed that in this context, the culprits use their power in office to delay and frustrate their victims until they succumb to the demands for bribe, as the case may be in Nigeria which is refers to "scratch my back I scratch your back". This kind of corruption has been branded "low level" and "street level" it manifests the citizens encounter daily at places like hospitals, schools, local licensing offices, police, and taxing office. This is seen as similar to "corruption of need" occur when one obtains a business from the public sector through inappropriate procedure. ${ }^{17}$

Electoral corruption includes purchase of votes with money, promises of offices, special favours, coercion, intimidation, and interference with freedom of election. This is mostly a common feature in Nigerian electoral process since independence. Votes are bought, people are killed or maimed in the name of election, losers end up as winners in elections, and votes turn up in areas where votes were not cast.

\section{THE DYNAMICS OF HYPOCRISY IN ANTI-CORRUPTION CAMPAIGN IN NIGERIA}

This section of the paper will deal with our attitude as Nigerians toward corruption and our hypocritical posture. Most people are linked with assets they could never have acquired even if they are to earn a million naira a month all their days in public office. And why do Nigerians think and believe that it is only the President, Governors and Ministers that can be corrupt? Until recently, who would have believed that a director in the civil service could keep N2 billion cash in his house. ${ }^{18}$ The so-called private sector may even be more corrupt than the public sector. After all, apart from direct filching of public funds, many instances of bribing are masterminded by the private sector. If we are going to be serious about the war against corruption in Nigeria we must first of all appreciate how pervasive it is and stop playing politics with its eradication.

The point stressed in this paper is that, Nigeria had had many anti-corruption agencies both civilian and military administrations which have all gone through public ridicule at the end of the day. The question of transparency become more pertinent in view of fact that, the standard have always been in the books but they have also been increasingly disregarded and mutilated in the actual operations by the officers.

The Shehu Shagari administration was written off as inept because of the magnitude of corruption in the administration, and its lack of policy direction. ${ }^{19}$ Abba etal captures it:

Not everybody for example knows that in spite of the billions of naira spent on the Green Revolution programme and the River Basin Authorities, the total production of most food did not rise at all. Where there was a rise, as in the case of maize, it was in replacement of other crops; and therefore this was used to justify a food import bill which rose from N818.8 million in 1979 to N1.16 billion in 1980 to N1.86 billion in the first nine months of 1981. This was a rise of food imports of over $100 \%$, in less than 3 years, in a country endowed with rich agricultural resources, most of whose people are farmers, and whose government had spent N100 billion ostensibly to boost food production. ${ }^{20}$

This point was buttressed by the corrupt practices of the government in the Green Revolution Programme and that of the River Basin Authority. In 1984, General Muhammadu Buhari addressing a diplomatic corps asserted that;

The economic plight of the country arising in part from the global economic recession but greatly accentuated by the mismanagement and rampant corruption of the dismissed administration could not have escaped your notice...the ordinary Nigerian who certainly has the fundamental right to leave indignity had become enslaved by a handful of Nigerians whose 
interest was only to perpetuate themselves in office at any cost, but also to share among themselves the wealth of the country, while the ordinary man wallowed deeper and deeper in misery. $^{21}$

Emerging views agreed that, the period between 1970 and 1983 was marked by the twin push of (a) The ruling class in Nigeria accumulating wealth through fraudulent importation of foreign food products, machinery, fertilizer, other chemicals and agricultural equipment; (b) Foreign firms wanting to sell cereals (particularly rice and wheat), fertilizer, equipment and machinery and livestock feeds in Nigeria. ${ }^{22}$ This was asserts by Buhari when he contended thus;

The otherwise buoyant economy of the first two fiscal years 1979/1980 was allowed to run down through mismanagement. The indiscipline in the former government's spending pattern was even more pronounced in the external sector of the economy. ${ }^{23}$

In 1985, cross sections of political gladiator were convicted of different forms of corrupt practices under the government of General Buhari. The regime of General Babangida never fight corruption, rather is seen as the body that legalized corruption. His administration refused to give account of the gulf war windfall, which is estimated to be $\$ 12.4$ billion. He cancelled the most successful election in the history of Nigeria June 121993 and lives in a very exquisite mansion in his home state Niger. The General Sani Abacha administration introduced a faceless War Against Indiscipline and Corruption (WAIC). The death of Abacha revealed the global nature of graft, French investigations of bribes paid to government officials to ease the award of a gas plant construction in Nigeria revealed the global level of official graft in the country. The investigations led to the freezing of accounts containing \$100 million United States Dollars.$^{24}$ In 2000,two years after his death, Swiss Banking Commission report indicted Swiss banks for failing to follow compliance process in allowing family and friends of Abacha access to accounts and depositing amounts totaling \$600 millions U S dollars into the accounts. The same year, a total of more than $\$ 1$ billion U S dollars were found in various accounts throughout Europe. $^{25}$

At the point chief Olusegun Obasanjo worked into the corridor of power in 1999, he resolved to tackle corruption. In his inaugural speech he inter-alia stated thus;

Corruption, the greatest single bane of our society today will be tackled head on at all levels. Corruption is incipient in all human societies and in most human activities. But it must not be condoned. This is why laws are made and enforced to check corruption, so that society would survive and develop in an orderly, reasonable and predictable way, no society can achieve anything near its full potential if it allows corruption to become the full-blown cancer it has become in Nigeria. One of the greatest tragedies of military rule in recent times, is that corruption was allowed to grow unchallenged and unchecked, even when it was glaring for everybody to see. The rules and regulations for doing official business were deliberately ignored, set aside or by-passed to facilitate corrupt practices. The beneficiaries of corruption in all forms will fight back with all the foul means at their disposal. We shall be firm with them; there will be no sacred cows. Nobody, no matter who and where, will be allowed to get away with the perpetration of corruption and evil, under this administration, therefore, all the rules and regulations designed to help honesty and transparency in dealings with government will be restored and enforced. Specially, I shall immediately reintroduce "civil service "rules" and "Financial instructions" and therefore compliance. Other regulations will be introduced to ensure transparency. The rampant corruption in the public service and the cynical contempt for integrity that pervades every level of the bureaucracy will be stamped out. The public officer must be encouraged to believe once again that integrity pays. His self-respect must be restored and his work must be fairly rewarded through better pay and benefits, both while in service and in retirement. ${ }^{26}$

On the $29^{\text {th }}$ September, 2000 when Olusegun Obansanjo inaugurated the independent Corrupt Practices and Other Related Offences Commission, he graphically summed it up thus;

With corruption there can be no sustainable development, nor political stability. By breeding and feeding on inefficiency, corruption invariably strangles the system of social organization. In fact, corruption is literally the antithesis of development and progress. ${ }^{27}$

That set the tone for Obansanjo's war against corruption. In fact it can be argued that at no time in the history of Nigeria was the war against corruption prosecuted with as much vigour as under the Obasanjo regime. The first challenge his government had, was the publication in the NEWS, in its July 111999 issue. 'The face of 
a liar' broke the news of 'forgery' and 'perjury' committed by the former Speaker of the House of Representatives, Alhaji Ibrahim Salisu Buhari. ${ }^{28}$ President Olusegun Obasanjo disappointed the world by granting Alhaji Salisu Buhari a state pardon, despite his apparent campaign to transform Nigeria into a corruption free society. The Buharigate as the scandal was later called, nearly destroyed Nigeria's democracy experiment. The president immodestly scored himself high in term of the war against corruption. In his address at the $10^{\text {th }}$ anniversary celebration of Transparency International in 2003, Obansanjo gave the impression that the war on corruption had been won. The address titled "Nigeria from pond of corruption to Island of integrity" seems as it has turned out to be a victory song in the heat of war.

The scenario and reality on the ground tells another story, shortly Olusegun Obansanjo left office, the revelations that have emerged about his presidency and its alleged involvement in corrupt practices, have put a lie to the anti-corruption posture of his government. In fact while he was in government, his involvement in political corruption was well documented. His alleged ownership of shares in Transcorp, the Presidential Library project and others readily come to mind. ${ }^{29}$ His involvement in corruption came full circle with the fraud that characterized the 2007 General Elections. ${ }^{30}$ Umaru Musa Yar'adua also promised, shortly after he was sworn in as President in May 2007 to intensify the war against corruption, more so because corruption is itself central to the ever rising spread of poverty, unemployment and misery of the people. ${ }^{31}$

However, about a year after President Yar'adua took over power in 2007, the Economic and Financial Crime Commission (EFCC) controversially cleared Obansanjo and many ex-Governors of any wrong-doing. In fact, the chairman of Economic and Financial Crime Commission (EFCC) Mrs. Farida Waziri declared the case files of these politicians missing. ${ }^{32}$ so in the case the EFCC attempted to prosecute the case involving the former Delta State Governor, James Ibori, the accused was controversially cleared of all charges of corruption against him. ${ }^{33}$ This controversial verdict has cast a long shadow on Yar'adua's commitment to the war on corruption. ${ }^{34}$ In fact a search light were turned on the then Attorney General and Minister of Justice over his perceived role in scuttling the trial of the former Governor of Delta state, Chief James Ibori. ${ }^{35}$

On separate occasion failures of the anti-corruption agencies have been admitted. Emmanuel Ayoola, chairman ICPC admitted that the anti-corruption war had failed. ${ }^{36}$ In a similar vein the former chairman of EFCC Mrs Farida Waziri admitted the failure of anti-corruption but has placed the blame on the international community. According to her the international community frustrates the anti-graft war because it benefits from the situation especially since most of the stolen monies are deposited in foreign accounts. ${ }^{37}$ In the views of Ken Achufuna, President Jonathan Goodluck cannot effectively tackle corruption in Nigeria because his hands are tied. He argued that Jonathan is incapacitated in the war against corruption because he is a product of a system that is corrupt. ${ }^{38}$ To fight corruption, he needs to have the will and vision. At the moment, such will and vision are not visible. Besides, he inherited an inchoate system characterized by bad laws. He further argues that many Nigerians see governance as a criminal enterprise where public treasurers are looted.

Within the educational sector in Nigeria, especially from secondary to university levels, corruption is very pervasive, and most of them are not in the public eye. Corruption in education includes corrupt practices by parents of students. Parents are known to have used unorthodox means to influence their children's or wards admission to secondary school, manipulate their final examinations. A high JAMB score is critical for admission in the university in Nigeria, and this has led to cheating by some students and parents. There are expensive coaching centres that charge exorbitant fees to guarantee a minimum score of 300 in the JAMB, which is been orchestrated by coaching centres through aiding and abetting cheating in JAMB examination with the connivance of JAMB officials. ${ }^{39}$ Corrupt practices by lecturers within the university system lead some students to resort to "sorting", finding ways of purchasing of high and unmerited mark from a lecturer in order to enhance the grade in their final examination.

The pervading corruption in the judiciary system. Prof. Sagay identified questionable injunctions granted by Nigerian courts as corruptible and a big problem for the country. He stated that such questionable injunctions almost ruined the 2011 general elections in the country, he further stressed that the irresponsible injunctions were a misuse of the powers of the courts. ${ }^{40}$ Attahiru Jega, INEC chairman, in his letter to the then Chief Justice of Nigeria (CJN), shortly before the general elections said;

My Lord, permit me to bring to your notice, the emerging trend in the political process where ex-parte orders are granted at the drop of a hat by judges particularly at the state and federal high courts. This is more worrisome where nearly all orders contradict one another. ${ }^{41}$

It is glaring that the regular courts are in-effective in attending to corrupt cases, such that high profile cases involving politicians drag on for many years without an end insight. On the other hand the suspects continue to enjoy their loots while their lawyers who are paid hefty fees deliberately prolong litigation endlessly. 


\section{MECHANISMS TO CONTROL CORRUPTION IN NIGERIA}

Every government in Nigeria has always recognized corruption as a major obstacle to development. For Nigeria to effectively tame the scourge of corruption in the society, we need to be re-oriented to a better value system. This is because Nigerians have for long been living on the survival of the fittest and grabwhatever-comes-your-way mentality. Dike Victor once asserts that; the re-orientation of the youth in Nigeria to a good value system could help in the war against corruption. ${ }^{42}$ Culture vs value and value vs corruption must be understood. I remember as a young chap growing in the village, the systematic manner of questions from our poor parents when you visited home with financial worth beyond your reach. This value and corruption can make a good point with experience of Sam Aluko with his parents in the late 1950.

Shortly after I returned from Britain in 1959, with a PhD in Economics... My wife and I were driven to the village in our new car which we purchased with money provided by the Nigeria College of Arts and Science and Technology, Ibadan, which was then my employer. After being well received by my family and the entire village community... my father and my mother came... and inquired very calmly but firmly how, so soon... I was able to possess a car. They were worried that I should not soil the family name by possessing vehicle beyond my financial capacity. When I told them that it was the Federal Government that bought the car for me, to repay the cost over time, they were greatly relieved. They did not want any corrupt allegations against me and against the family... And it was one of the smallest cars of that era. Now, in the same village, some of my family members pooh-pooh me for coming to the village in a Peugeot station wagon car when even junior public officers and minor political office holders ride the latest Jeeps, Mercedes Benz and other cars out the ordinary. ${ }^{43}$

The problem of corruption is basically the issue of good governance. once good governance practices are entrenched, corruption would be on the decline. However, in the last decade in Nigeria, the war on corruption has not been successful because the government in itself has been less than honest in its so called war on corruption. A lot of the actions of the government have shown that it has only paid lip service to the problem of corruption.

For effective control of corruption in Nigeria, the society must develop a culture of relative openness, in contrast to the current bureaucratic climate of secrecy. And a merit system (instead of the tribal bias, state of origin and nepotism or favoritism, which have coloured the landscape) Fairness and equity should be adopted in employment and distribution of national resources, etc. More importantly, the leadership must muster the political will to tackle the problem head-on.

There should be ethical standard throughout the agencies of government and business organizations in Nigeria. In the words of Bowman, ethics is action, the way we practice our values; it is a guidance system to be used in making decisions. The issue of ethic in public sector (and in private life) encompasses a broad range, including a stress on obedience to authority, on the necessity of logic in moral reasoning, and on the necessity of putting moral judgment into practice. ${ }^{44}$ This is due to the fact that, many office holders in Nigeria (appointed or elected) do not unfortunately, have clear conceptions of the ethical demands of their position. Poor reward system and greed. Nigeria's reward system is, perhaps, the poorest in the world. Nigeria is a society where national priorities are turned upside down; hard work is not rewarded, but rogues are often glorified in Nigeria.

\section{Conclusion}

The paper examines that, the motive for corruption is to take undue advantage of position of trust which is not limited to pecuniary issues. It is also not limited to the public sector. The act is criminal when considered along with the existing legislations on the subject in Nigeria. The paper observed that, most governments in Nigeria has set up one anti-graft or an anti-corruption agency to check the menace of corruption, in spite of these efforts, the level of corruption is still of serious concern and remains the greatest challenge to our development. As Ezonbi, Boumo observes that; it is often remarked that the British will not conclude the day without mention of the weather, in Nigeria, the economy, power and corruption will top the list of daily discussions, that is, when we are not talking about other people's wealth and the size of the loot, unlike the British that cannot do much about their weather, so also Nigerians cannot do anything about corruption. ${ }^{45}$ The paper concludes, that, the proponent of transparency or those fighting corruption are the once caught in the act, give the chance, they out steal the people they were criticizing or "the hunter becomes the hunted" in other words, the thief and the "catcher" easily trade places. Finally, discipline, rule of law, accountability, good governance and transparency are the keys to tackling corruption in Nigeria. 


\section{Endnotes}

[1]. M.M Yusif "Causes and Effects of Corruption on Society Development a Paper Presented at a Seminar Organised by the Code of Conduct Bureau Dutse, Jigawa State 2000. P. 2

[2]. M, Ruzindanu, Quoted in O.A Oyinlola "Corruption Eradication in Nigeria: An Appraisal in the Newswatch june $20^{\text {th }} 2012$ P. 1

[3]. U.N on Corruption Quoated in P. Eigen Global Corruption Report 2001, Transparency International edited by Hodess, R, Banifield, J and Wolfie, T. 2001 P. 5

[4]. Independent Corrupt Practices and Other Related Offences Commission: Anti-Corruption Tools for Persecution and Investigation Manual 2000. P.6

[5]. A.F Ndubisi "Counter Productive Effects of Corruption on Social and Economic Development" in Odekunle Femi (ed) Corruption in Development. Ibadan, Ibadan University Press 1986. P. 60

[6]. The World Bank Quoted in Y.A Aluko "Corruption in Nigeria: Concept and Dimension" in D.U Emweremadu and E.F Okafor (eds) Anti-Corruption Reforms in Nigeria Since 1999: Issues, Challenges and the Way Forward. IFRA Special Research Issue Vol. 3 2009. Pp. 1-18

[7]. J.S Daniel 2007 Quoted in J.O Erunke, Sulieman, Y and Olatise, M.A "Curbing Corruption in the Executive Arms of Government 2003-2007. Being A Paper Presented at the Two Day International Conference Organised by the Department of Political Science Nasarawa State University Keffi. from $20^{\text {th }}-22^{\text {nd }}$ May 2012. P. 20

[8]. J.S Nye "Corruption and Political Development. A Case Benefit Analysis" The American Political Science Review, 1967. Pp. 417427

[9]. Banfield, Edward. The Moral Basis of Backward Society. Chicago. Free Press. 1958. P. 40

[10]. S.O Osoba "Corruption in Nigeria: Historical Perspectives" Review of African Political Economy Vol. 23 1996. Pp. $523-537$

[11]. C.W Gray and D. Kaufmann "Corruptioin and Development” http//www.worldbank.com/fand/English/0398/article/020398/htm.see world Bank Report 2000 accessed form www.worldbank.org/corruption 20/09/2011

[12]. C.W Gray and D. Kaufmann "Corruptioin and Development” http//www.worldbank.com/fand/English/0398/article/020398/htm.see world Bank Report 2000 accessed form www.worldbank.org/corruption 20/09/2011

[13]. NORAD, Ch. 4, Jan. 2000; the Encyclopedia America 1999. P. 8

[14]. Dogonyaro, Joshua Commenting on Corruption in Nigeria in Public Lecture Delivered in Lagos in the Daily Trust May $23^{\text {rd }} 2011$ P.10

[15]. D.J Gould, Bureaucratic Corruption and Under-development in the Third World: The Case of Zaire. New York Pergaman 1980. P. 40

[16]. H.N Left "Economic Development Through Bureaucratic Corruption" In M.U Ekpo (ed) Bureaucratic Corruption in Sub-Saharan Africa. Toward a Search for Causes and Consequences Washington D.C University Press of America 1979. P. 20

[17]. NORAD, chapter 4. 2000 P. 10

[18]. Stolen 2 Billion Naira Pensioners Fund Newswatch Editorial March $20^{\text {th }} 2012$.

[19]. R.C Suberu "The Democratic Recession in Nigeria” Current History, May 1994. Pp. 213-216

[20]. A, Abba, etal. The Nigerian Economic Crises: Causes and Solution. Published by Academic Staff Union of Universities of Nigeria 1985. P. 50

[21]. General Muhammadu Buhari Address to the Diplomatic Corps Gathering in Newswatch $24^{\text {th }}$ May, 1984 P. 15

[22]. A. Abba, etal The Nigerian Economic Crises: Causes and Solution.... P. 52

[23]. General Mohammadu Buhari Commenting of the Pervasive Corruption that Rock the Nigrian Economy During the Second Republic in Newswatch March $20^{\text {th }} 1984$. P. 12

[24]. Hector, Igbikiowubo “Tskj Saga: Swiss Government Freezes \$ 100m Accounts” Vanguard Nigeria December 6. 2004 P.10

[25]. Obasanjo, Obasanjo 'Inaugrual Address' Federal Ministry of Information Abuja 2000.

[26]. David Pallister “Comment and Analysis: Pennies from Heaven: Many of Nigeria's Missing Millions were Laundered through Greedy Banks in (London)" the Guardian London September 7. 2000 P. 8

[27]. ICPC Inaugurated Sept. $29^{\text {th }} 2000$ in Daily trust 30 September, 2000 P.12

[28]. The News a Weekly Magazine "The Face of a Liar" July 11, 1999. P.6

[29]. A, Philips "More Troubles for Obasanjo" Newswatch April 14 2008. P. 35-36. See also J.S Omotola "Through a Glass Darkly: Assessing the New Insight 36 (3) 2006 Pp. 214-228

[30]. Egwemi, Victor "Political Corruption and the Challenges of Sustainable Development in Nigeria: Focus on third Term Agenda" in NASHER Journal 4 (1) 2007: Pp. 178-185

[31]. Umar Musa Yar'Adua Inauguration Speech Daily Trust $30^{\text {th }}$ May, 2007 P. 4

[32]. J. Ojo "Corruption: EFCC clears Obasanjo, Ex-Governors" Daily Sun October 14 2008. P. 4

[33]. M. Osayande and B. Edet "Money Laundering: Court Frees Ibori" Daily Trust December 18 2009.Pp. 1 and 5

[34]. B. Omonijo "Corruption: Can Yar'adua Tame this Monster/" The Nation Sunday August 17. 2009. Pp. 49-51.

[35]. T. Adisa "Between EFCC and Aondoaka" Saturday Tribune 26 Sept. 2009. P. 28

[36]. Nigerian Tribune July 2009 Editorials

[37]. B. Edet "International Community Frustrates Anti-Graft War" Daily Trust Tuesday June 9. 2009. P. 3

[38]. Achufuna, Ken "Jonathan Cannot Effectively Tackle Corruption in Nigeria" Newswatch August 132012 P. 27

[39]. The Author's Stint with the Nasarawa State Ministry of Education for Over 6 years.

[40]. Professor, E I Sagay in Public Lectures in Lagos see Newswatch August 13, 2012 P. 27

[41]. Attaihu, Jega Letter to Chief Justice of Nigeria (CJN) on 2011 General Election Daily Trust February 142011

[42]. V.E Dike "The Philosophy of Transforming Nigeria into a Corruption - Free Society: Are the Probes the Solution? Online Publication Nigeriaworld:com/feature/article/corruption.html.october 6. 1999. P. 10

[43]. S.A Aluko "Corruption and National Development, Bala Yusufu Usman Annual Memorial Lecture. Centre for Democratic Development Research and Training CEDDERT, Zaria. 2008

[44]. J.S Bomwan, "Introduction: Ethical Theory and Practice in Public Management" in Ethical Frontier in Public Management Seeking New Strategies for Resolving Ethical Dilemmas; James S. Bomwan, Editor, San Francisca Jossey Base, 1991. P. 42

[45]. Ezonbi, Boumo "Corruption as the Bane of Urban Decay in Nigeria: Periscoping the Nasarawa West Senatorial District of Nasarawa State, 1999- 2011 Proceeding of the $56^{\text {th }}$ Annual Congress of the Historical Society of Nigeria. Osun State University,Osogbo. 2011 P. 1 